\title{
Epidemiology of Strawberry pallidosis-associated virus and Occurrence of Pallidosis Disease in North America
}

Ioannis E. Tzanetakis, Department of Botany and Plant Pathology, Oregon State University, Corvallis 97331; William M. Wintermantel and Arturo A. Cortez, USDA-ARS, 1636 E. Alisal Street, Salinas, CA93905; Janelle E. Barnes and Stephanie M. Barrett, Horticultural Crops Research Laboratory, USDA-ARS, Corvallis, OR 97330; Mark P. Bolda, University of California Cooperative Extension, Watsonville 95076; and Robert R. Martin, Horticultural Crops Research Laboratory, USDA-ARS, Corvallis, OR 97330

\begin{abstract}
Tzanetakis, I. E., Wintermantel, W. M., Cortez, A. A., Barnes, J. E., Barrett, S. M., Bolda, M. P., and Martin, R. R. 2006. Epidemiology of Strawberry pallidosis-associated virus and occurrence of pallidosis disease in North America. Plant Dis. 90:1343-1346.

Strawberry pallidosis-associated virus ( $\mathrm{SPaV})$ was found closely associated with pallidosis disease. The modes of transmission of the virus were studied, including pollen, seed (achene), and whitefly transmission. Three whitefly species were tested for their ability to transmit SPaV, but only the greenhouse whitefly, Trialeurodes vaporariorum, was identified as a vector of the virus. Testing strawberries for SPaV and Beet pseudo yellows virus (BPYV), a second crinivirus associated with pallidosis disease, in strawberry-producing areas in North America confirmed a high incidence of both viruses in areas where high populations of whiteflies were present. Infection rates as high as $90 \%$ for $\mathrm{SPaV}$ and $60 \%$ for BPYV were observed when plants exhibiting decline symptoms were tested. Lower rates of infection were found in regions where whiteflies were absent or found in low numbers. The role of these criniviruses in the strawberry decline observed over the past few years along the western coast of North America was examined.
\end{abstract}

Strawberry pallidosis disease (PD) was first recognized in 1957 in both Australia and the United States, but it is considered indigenous to North America since the infected Australian plants originated in the United States (4). By definition, PD is a graft-transmissible disorder causing chlorosis and epinasty on Fragaria virginiana clones 'UC-10' and 'UC-11', whereas $F$. vesca clones 'UC-4' and 'UC-5' remain asymptomatic (4). A survey in Maryland, USA, in 1998 identified PD as the most widespread of the graft-transmissible diseases of strawberry (6), an unexpected result given that until then PD was considered a rarity. Recent studies have identified two viruses, Beet pseudo yellows virus (BPYV) and Strawberry pallidosisassociated virus (SPaV), two members of the genus Crinivirus, family Closteroviridae, to be associated with the disease $(11,14)$. Criniviruses are transmitted in a semipersistent manner by whiteflies (Sternorrhyncha: Aleyrodidae) of the genera Bemisia and Trialeurodes. The viruses have been an emerging problem for agriculture mainly as a result of the naturalization of their vectors in areas where they

Corresponding author: I. E. Tzanetakis

E-mail: yannis@ orst.edu

Accepted for publication 5 June 2006.

DOI: 10.1094/PD-90-1343

(C) 2006 The American Phytopathological Society were previously absent $(16,19)$, while new members and hosts are identified continually $(8,9,12,15)$.

Pallidosis is latent in most modern strawberry cultivars, but anecdotal data indicated that the agents may be part of a virus complex that causes decline symptoms (5). Beginning in 2000, decline symptoms were observed in strawberries along the west coast of North America. Preliminary data identified $\mathrm{SPaV}$ and BPYV at a high incidence in the plants exhibiting decline in California (10), and thus epidemiological studies were carried out to acquire better knowledge of these newly identified pathogens of strawberry.

This study examined pollen, seed (achene), and insect transmission of SPaV. The host range of $\mathrm{SPaV}$ was evaluated using transmission by Trialeurodes vaporariorum. Testing for $\mathrm{SPaV}$ and $\mathrm{BPYV}$ were carried out in strawberry nurseries and fields of North America to estimate the presence of the viruses and their importance in the strawberry decline.

\section{MATERIALS AND METHODS}

Pollen and seed (achene) transmission. Horizontal transmission to maternal plants via pollen trials was performed on 170 strawberry plants of cultivars Noreaster and Hood. Plants were emasculated at the flower white tip stage, and the receptacle was allowed to mature for 2 to 5 days before pollination. The plants were pollinated using a paint brush with a mixture of pollen collected from $20 \mathrm{SPaV}$-infected strawberry plants from Maryland (11) and allowed to set fruit under greenhouse conditions ( 16 to $22^{\circ} \mathrm{C}, 12$ - to 14 -h photoperiod). Fruit was collected at maturity. Three months after fruit collection, plants were cold-treated for at least 30 days $\left(4^{\circ} \mathrm{C}\right.$, $12 / 12 \mathrm{~h}$ photoperiod). After vernalization, plants were grown for at least 2 months in a greenhouse (16 to $22^{\circ} \mathrm{C}, 12$ - to $16-\mathrm{h}$ photoperiod) prior to nucleic acid isolation and reverse transcription-polymerase chain reaction (RT-PCR) testing $(11,14$; Table 1).

Evaluation of seed (achene) transmission of SPaV was conducted in 410 strawberry seedlings. Forty seedlings grown from achenes of infected plants pollinated with pollen from healthy sources and 370 seedlings that originated from achenes where pollen from the SPaV-infected source was used to pollinate healthy plants were tested. Seedlings were grown for at least 3 months after emergence under greenhouse conditions $\left(16\right.$ to $22^{\circ} \mathrm{C}, 12$ - to 16-h photoperiod) and tested for the presence of the virus by RT-PCR.

Whitefly transmission. The greenhouse whitefly ( $T$. vaporariorum), the bandedwing whitefly ( $T$. abutilonea), and the silver-leaf whitefly (Bemisia tabaci biotype B) were evaluated for their ability to transmit $\mathrm{SPaV}$. One hundred whiteflies were allowed to feed for $48 \mathrm{~h}$ on strawberry plants infected with the SPaV Mary-

Table 1. List of oligonucleotide primers used for reverse transcription-polymerase chain reaction of Strawberry pallidosis-associated virus (SPaV) and Beet pseudo yellows virus (BPYV)

\begin{tabular}{llc}
\hline Primer name & Nucleotide sequence $\left(\mathbf{5}^{\prime} \mathbf{-} \mathbf{3}^{\prime}\right)$ & Length $\mathbf{( b p )}$ \\
\hline SPaV HSP70hF & GTGTCCAGTTATGCTAGTC & 517 \\
SPaV HSP70hR & TAGCTGACTCATCAATAGTG & \\
SPaV p28F & AATGCTACCTCCTATACCAATGC & 600 \\
SPaV p28R & AAGCCTGTCGTGGAGAACTT & \\
BPYV CPmF & TTCATATTAAGGATGCGCAGA & 334 \\
BPYV CPmR & TGAAAGATGTCCRCTAATGATA & \\
\hline
\end{tabular}


land isolate M2. Only strawberry plants with high levels of $\mathrm{SPaV}$, as measured by strong signals in nucleic acid spot hybridization, were used as source plants. The original M2 plant tested free of all other known strawberry viruses (7). Following acquisition, whiteflies were transferred to Nicotiana benthamiana or Physalis wrightii test plants, and allowed a 48-h inoculation access period. A total of three experiments of at least five plants per vector species were performed in the vector identification studies.

For both acquisition and transmission time experiments, $N$. benthamiana plants were used as test plants. Virus source plants consisted of either strawberry or $N$. benthamiana containing high levels of $\mathrm{SPaV}$ as measured by strong signals in nucleic acid spot hybridization using a SPaV-specific probe (see below). For acquisition time estimation, whiteflies ( $T$. vaporariorum) were fed on source plants for $2,6,12,24$, and $48 \mathrm{~h}$ and were then transferred in clip-on leaf cages to test plants. Cages were removed and whiteflies killed $48 \mathrm{~h}$ after transfer using the contact insecticide Resmethrin (PT-1200) (Whitmire Research Laboratories, St. Louis, MO). Transmission time was evaluated by allowing whiteflies a $48-\mathrm{h}$ acquisition time followed by transfer to test plants for a 2 , $6,12,24$, and $48 \mathrm{~h}$ transmission period before Resmethrin application. Each experiment consisted of five plants per time period and was repeated twice.

Three experiments of six or seven plants per experiment were performed to evaluate separately the efficiency of transmission of SPaV and BPYV to strawberry and $N$. benthamiana, another common host used as a control (Table 2). Whiteflies were allowed a 48-h acquisition period on infected strawberry leaves and confirmed to have sufficient levels of SPaV or BPYV by hybridization as previously described. Subsequently, 75 viruliferous whiteflies were collected, placed in leaf cages, and fed on test plants for an additional $48 \mathrm{~h}$ before Resmethrin application. Six weeks postinoculation, total nucleic acid was extracted from plants and tested for the presence of $\mathrm{SPaV}$ or BPYV by either RTPCR (11) or RNA hybridization (Fig. 1). Clones for probe synthesis and detection of $\mathrm{SPaV}$ were constructed by RT-PCR and cloning of a 752-nucleotide segment of the $\mathrm{SPaV}$ coat protein region (11) encompass-

Table 2. Transmission frequency of Strawberry pallidosis-associated virus (SPaV) and Beet pseudo yellows virus (BPYV) with the greenhouse whitefly (Trialeurodes vaporariorum)

\begin{tabular}{lcc}
\hline & \multicolumn{2}{c}{ Plant species } \\
\cline { 2 - 3 } Virus & $\begin{array}{c}\text { Fragaria } \times \\
\text { ananassa }\end{array}$ & $\begin{array}{c}\text { Nicotiana } \\
\text { benthamiana }\end{array}$ \\
\hline BPYV & $8 / 21(38 \%)$ & $16 / 20(80 \%)$ \\
SPaV & $3 / 21(14 \%)$ & $3 / 20(15 \%)$ \\
\hline
\end{tabular}

ing nucleotides 4267 to 5017 (13). The RTPCR product was cloned using the TOPO TA Cloning Kit (pCRII-TOPO, Invitrogen, Carlsbad, CA) and used to transform Escherichia coli (TOP10 cells, Invitrogen, Carlsbad, CA) using standard conditions. Probe synthesis was by in vitro transcription using the $\mathrm{T} 7$ promoters and labeling with the DIG RNA Labeling Kit (Roche, Indianapolis, IN). Hybridization and detection involved standard procedures as recommended by the manufacturer.

Experimental host range. Twenty-two plants species were tested as potential hosts of SPaV (Table 3). Strawberry source plants were tested for the presence of sufficient levels of SPaV immediately prior to transmission experiments. Only those plants with high levels of $\mathrm{SPaV}$, as measured by strong signals in nucleic acid spot hybridization, were used as source plants. Whiteflies were fed on $\mathrm{SPaV}$-infected plants for $48 \mathrm{~h}$ to assure acquisition of the virus. Clip-on leaf cages containing 75 to 100 whiteflies (T. vaporariorum) were then transferred to individual test plants for $48 \mathrm{~h}$. Cages were removed, and insects were killed with Resmethrin. One week postinoculation, the inoculated leaf was removed to prevent any nymphs from maturing. Plants were transferred to the greenhouse and maintained for 6 weeks. At 5 weeks postinoculation, total RNA was extracted from a mature, presenescent, noninoculated leaf. RT-PCR and RNA spot hybridization were conducted with $\mathrm{SPaV}$-specific primers and probes, respectively, for the presence of SPaV. A minimum of five to eight plants were tested per species along with control inoculations of strawberry and/or $N$. benthamiana except for Duchesnea indica where three plants were used.

Geographic distribution. More than 680 plants from strawberry fields and nurseries in California, Oregon, Washington, British Columbia, and Florida (Table 4) were tested for the presence of $\mathrm{SPaV}$ and BPYV during the growing periods 2003 to 2005 using RT-PCR (Fig. 1). These plants were also tested for Strawberry mild yellow edge, Strawberry crinkle, Strawberry mottle, and Strawberry vein banding viruses, the four major aphidborne viruses commonly found in strawberry (7).

\section{RESULTS AND DISCUSSION}

There has been anecdotal evidence that PD is pollen transmissible (1). These claims led to the investigation of the possibility of pollen transmission of $\mathrm{SPaV}$, although there are no previous reports of closteroviruses being pollen transmitted. Pollen from SPaV-infected strawberry plants was used to pollinate 170 strawberry plants, but none developed SPaV infections by the conclusion of these studies. Seed (achene) transmission from both maternal and paternal sources was also tested, but none of the seedlings tested were infected with the SPaV.

Frazier (1) claimed that PD was pollen transmitted. The results presented here suggest that the agent Frazier was referring to as pollen transmissible was probably not $\mathrm{SPaV}$. It is possible that BPYV, a related crinivirus that can cause PD, or another asyet-undescribed agent associated with PD may be responsible for the transmission observed in Frazier's studies. The possibility of another as-yet-undescribed agent may be plausible since there is a report of PD transmission with leafhoppers (3), efficient vectors of a number of viruses. A more likely possibility is that there were $T$. vaporariorum in the greenhouse when the leafhopper studies were conducted, but these were dismissed as vectors since at

\section{A}

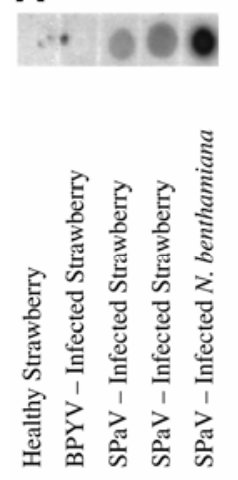

B

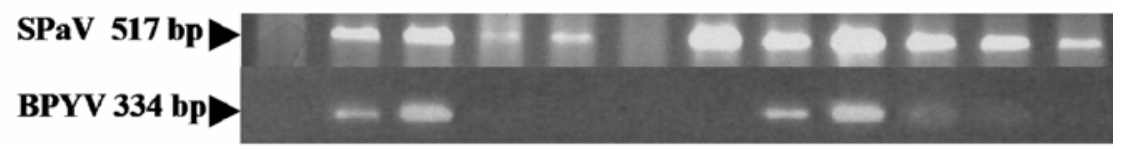

Fig. 1. A, Dot spot hybridization for detection of whitefly transmission of Strawberry pallidosisassociated virus $(\mathrm{SPaV})$. B, Reverse transcription-polymerase chain reaction detection of field material of SPaV (top) and Beet pseudo yellows virus (BPYV) (bottom). Lane 1, healthy control; lane 2, positive control; lanes 3 to 12 , field material from California. 
that time whiteflies were not known to vector strawberry viruses.

T. vaporariorum, the greenhouse whitefly, has been identified as a vector of $\mathrm{SPaV}$ (17 of 20 test plants infected). No transmission was detected when transmissions were conducted using $T$. abutilonea or $B$. tabaci biotype B. The inability of T. abutilonea or B. tabaci biotype B to transmit the virus indicates that they are not vectors of SPaV. At the very most, transmission rates with these two species are so low that their ability to transmit $\mathrm{SPaV}$ is inconsequential and likely would not lead to any significant spread under natural conditions. All criniviruses characterized to date are known to be transmitted by $B$. tabaci biotypes, T. abutilonea, or T. vaporariorum (16). B. tabaci biotype A was not included in testing because it no longer exists in the field due to displacement by the B biotype (18). The genetic similarity between $\mathrm{SPaV}$ and BPYV (13), both of which are believed to be transmitted exclusively by $T$. vaporariorum, further supports the likelihood that $T$. vaporariorum is the principal vector of $\mathrm{SPaV}$ in the field. Although the whitefly species tested in these studies include all species known as virus vectors in North America, it remains possible that there are other whitefly species in strawberry that could potentially transmit $\mathrm{SPaV}$.

Limited tests indicated that $\mathrm{SPaV}$ can be acquired by the greenhouse whitefly from infected source plants in as little as $6 \mathrm{~h}(1$ of 10 test plants infected), but efficiency of transmission was higher with a 48 -h acquisition access period (AAP) (4 of 14 test

Table 3. Host range of Strawberry pallidosisassociated virus (SPaV) utilizing Trialeurodes vaporariorum for transmission

\begin{tabular}{lc}
\hline Plant species tested & $\begin{array}{c}\text { Infected/ } \\
\text { inoculated }\end{array}$ \\
\hline Fragaria $\times$ ananassa & $3 / 10$ \\
Sibbaldia procumbens & $3 / 8$ \\
Duchesnea indica & $0 / 3$ \\
Nicotiana benthamiana & $6 / 10$ \\
N. glutinosa & $0 / 5$ \\
N. clevelandii & $2 / 5$ \\
N. tabacum & $0 / 5$ \\
Physalis wrightii & $5 / 6$ \\
P. floridana & $0 / 5$ \\
Malva parviflora & $2 / 5$ \\
Citrullus spp. & $0 / 5$ \\
Chenopodium murale & $0 / 5$ \\
C. capitatum & $0 / 5$ \\
C. amaranticolor & $0 / 5$ \\
Gomphrena globosa & $0 / 5$ \\
Capsella bursa-pastoris & $0 / 5$ \\
Brassica oleracea var. italica & $0 / 5$ \\
Lycopersicon esculentum & $0 / 5$ \\
Beta vulgaris & $0 / 5$ \\
B. maritima subsp. macrocarpa & $0 / 5$ \\
Datura stramonium & $0 / 5$ \\
Urtica urens ${ }^{\mathrm{a}}$ & $0 / 5$ \\
\hline
\end{tabular}

a SPaV has also been found in field isolates of nettle (Urtica sp.) associated with high field populations of greenhouse whitefly. It is not known if field isolates were $U$. urens or another Urtica species. plants infected). SPaV is not as efficiently transmitted by $T$. vaporariorum as BPYV (Table 2), however. BPYV can be transmitted by individual whiteflies (2), whereas transmission of SPaV has not been found to date using individual whiteflies (data not shown). Furthermore, relatively large numbers of whiteflies (75 per plant) with 48-h AAPs and 48-h transmission access periods resulted in much lower levels of SPaV transmission than BPYV transmission in side-by-side comparisons of transmission efficiency (Table 2), suggesting that field movement may occur much more readily with BPYV than with $\mathrm{SPaV}$.

In the original study that identified $\mathrm{SPaV}$ as a putative causal agent of $\mathrm{PD}, 37$ of the 38 PD-positive plants were infected with $\mathrm{SPaV}$, identifying it as the predominant virus causing the disease. BPYV was found in approximately $25 \%$ of the plants, with only one found free of SPaV (11). California was found to be the most heavily infested area, with $29 \%$ of plants from fruit production fields testing positive for $\mathrm{SPaV}$, whereas $21 \%$ were positive for BPYV (Table 4). Incidence in symptomatic plants near Irvine, CA, reached $90 \%$ for SPaV and $60 \%$ for BPYV in 2003. Among the symptomatic plants showing decline symptoms, approximately $72 \%$ of the plants in California were infected with $\mathrm{SPaV}$ and $40 \%$ with BPYV, whereas in Washington and British Columbia none of the symptomatic plants identified were determined to be infected with either crinivirus and no whiteflies were found on the plants over the 3-year sampling. In these areas, the decline was only associated with the presence of the four major aphid-borne strawberry viruses (7). Experiments are currently underway to identify the synergisms caused by the criniviruses when found in mixed infections with the major aphid-borne strawberry viruses. Results may clarify the role of SPaV and BPYV in strawberry decline.

It remains to be determined if field infection by $\mathrm{SPaV}$ or BPYV is primarily the result of field movement of these viruses from infected weed and crop hosts, or if infection is the result of contaminated nursery material. Prior to 2002, the causal agent of PD had not been determined $(11,14)$, and BPYV was not known to infect strawberry (14). The very low incidence of BPYV and $\mathrm{SPaV}$ in Oregon, Washington, and British Columbia, where whiteflies have not been observed on strawberries in the field, suggests that whitefly transmission of these viruses in the production fields in California may be primarily responsible for the high incidence of PD there. Supporting this is the correlation of PD with high field populations of T. vaporariorum in 2002 and 2003 in California production fields.

Both SPaV and BPYV have been identified in nursery stock (Table 4), and efforts are in progress to monitor and eradicate these viruses from nursery plants. Field movement remains an important potential source of spread, however, and will be examined further for its impact on virus prevalence and disease development. It is possible that $\mathrm{SPaV}$ can be efficiently transmitted in the presence of a helper virus, even with whitefly species other than $T$. vaporariorum, as shown for Tomato chlorosis virus and Tomato infectious chlorosis virus (17). This may be an important mode of dissemination of $\mathrm{SPaV}$, especially in light of the discovery of a third, widespread crinivirus in strawberry (I. E. Tzanetakis and R. R. Martin, unpublished data).

The host range evaluation of $\mathrm{SPaV}$ indicated that the virus has a narrow host range. This is the case of most criniviruses; however, BPYV has a much wider host range than most $(2,19)$. The known host range of $\mathrm{SPaV}$ is limited to seven plant species among the 22 species tested (Table 3). Interestingly, burning nettle (Urtica urens) was not infected by $\mathrm{SPaV}$ in transmission tests, although nettle plants near strawberry fields have been confirmed infected by $\mathrm{SPaV}$ on more than one occasion. A possible explanation is that the field nettle identified as $U$. urens may in fact have been another species of nettle ( $U$. dioica), which is also present in California. Seed of $U$. dioica was not available for testing.

The data obtained from this study have helped to decrease the incidence of strawberry decline in California, where growers are now actively controlling virus vectors, a practice not common in annual production systems. Our efforts are now focusing on integrated pest management systems that will minimize the incidence of strawberry decline in areas where the disease persists.

\section{ACKNOWLEDGMENTS}

The authors acknowledge the usually helpful discussions during the course of the studies on pallidosis disease with Dr. R. H. Converse. The

Table 4. Results of strawberry plants tested for Strawberry pallidosis-associated virus (SPaV) and Beet pseudo yellows virus (BPYV) in nurseries and major strawberry-producing areas of North America

\begin{tabular}{lccccc}
\hline & \multicolumn{5}{c}{ Region } \\
\cline { 2 - 6 } Virus & California & Oregon & Washington & Florida & Canada \\
\hline SPaV & $36 / 521^{\mathrm{a}}$ & $1 / 26$ & $0 / 78$ & $0 / 23$ & $0 / 33$ \\
BPYV & $26 / 521^{\text {a }}$ & $2 / 26$ & $0 / 78$ & $3 / 23$ & $2 / 33^{\mathrm{b}}$ \\
\hline
\end{tabular}

a This includes 397 samples from nurseries, which all tested negative.

b Plants acquired from certification program. 
project was funded by the California Strawberry Commission, the North America Strawberry Grower's Association, and the United States Department of Agriculture.

\section{LITERATURE CITED}

1. Converse, R. H. 1992. Modern approaches to strawberry virus research. Acta Hortic. 308:1930.

2. Duffus, J. E. 1965. Beet pseudo-yellows virus, transmitted by the greenhouse whitefly (Trialeurodes vaporariorum). Phytopathology 55:450-453.

3. Frazier, N. W. 1975. Possible transmission of strawberry pallidosis by the leafhopper Coelidia olitoria. Plant Dis. Rep. 59:40-41.

4. Frazier, N. W., and Stubbs, L. L. 1969. Pallidosis - A new virus disease of strawberry. Plant Dis. Rep. 53:524-526.

5. Fulton, J. P. 1987. Strawberry Pallidosis. Pages 55-56 in: Virus Diseases of Small Fruit. R. H. Converse, ed. U.S. Dep. Agric. Agric. Res. Serv. Agric. Handb. 631.

6. Martin, R. R., Hokanson, S. C., Maas, J. L., Heflebower, R. F., and Rouse, R. 2001. Survey of strawberry viruses occurring in commercial plantings in the state of Maryland, USA. Acta Hortic. 551:71-74.

7. Martin, R. R., and Tzanetakis, I. E. 2006.
Characterization and recent advances in detection of strawberry viruses. Plant Dis. 90:384396.

8. Martin, R. R., Tzanetakis, I. E., Gergerich, R., Fernandez, G., and Pesic, Z. 2004. Blackberry yellow vein associated virus: A new crinivirus found in blackberry. Acta Hortic. 656:137-142.

9. Segundo, E., Martin, G., Cuadrado, I., and Janssen, D. 2004. A new yellowing disease in Phaseolus vulgaris associated with a whiteflytransmitted virus. Plant Pathol. 53:517.

10. Tzanetakis, I., Bolda M., and Martin, R. 2004. Identification of viruses in declining strawberries along the west coast of North America. (Abstr.) Phytopathology 94:S104.

11. Tzanetakis, I. E., Halgren, A. B., Keller, K. E., Hokanson, S. C., Maas, J. L., McCarthy, P. L., and Martin, R. R. 2004. Identification and detection of a virus associated with strawberry pallidosis disease. Plant Dis. 88:383-390.

12. Tzanetakis, I. E., and Martin, R. R. 2004. First report of Beet pseudo yellows virus in blackberry in the United States. Plant Dis. 88:223.

13. Tzanetakis, I. E., Reed, J., and Martin, R. R. 2005. Nucleotide sequence, genome organization and phylogenetic analysis of Strawberry pallidosis associated virus, a new member of the genus Crinivirus. Arch. Virol. 150:273286.
14. Tzanetakis, I. E., Wintermantel, W. M., and Martin, R. R. 2003. First report of Beet pseudo yellows virus in strawberry in the United States: A second crinivirus able to cause pallidosis disease. Plant Dis. 87:1398.

15. Wintermantel, W. M. 2004. Pumpkin (Cucurbita maxima and $C$. pepo), a new host of Beet pseudo yellows virus in California. Plant Dis. 88:82.

16. Wintermantel, W. M. 2004. Emergence of greenhouse whitefly (Trialeurodes vaporariorum) transmitted criniviruses as threats to vegetable and fruit production in North America. APSnet feature article June 2004. Online publication.

17. Wintermantel, W. M., and Cortez, A. A. 2001. Complementation for transmission by nonvector whiteflies among tomato-infecting criniviruses. (Abstr.) Phytopathology 91:S96.

18. Wisler, G. C., and Duffus, J. E. 2001. Transmission properties of whitefly-borne criniviruses and their impact on virus epidemiology. Pages 293-308 in: Virus-Insect-Plant Interactions. K. F. Harris, O. P. Smith, and J. E. Duffus, eds. Academic Press, San Diego, CA.

19. Wisler, G. C., Duffus, J. E., Liu, H.-Y., and Li, R. H. 1998. Ecology and epidemiology of whitefly-transmitted closteroviruses. Plant Dis. 82:270-279. 